Julita DZIAŁAK

Poznań

\title{
Międzynarodowa ochrona korespondentów wojennych
} $W_{\text {zaczęli tworzyć organizacje i instytucje mające chronić reporterów }}^{\text {kwestii polepszania ochrony korespondentów, sami dziennikarze }}$ czy też gromadzić i rozpowszechniać informacje, pozwalające im bezpieczniej wykonywać profesję korespondenta wojennego. Najpoważniejszą instytucją w tej mierze jest International Federation of Journalists z siedzibą w Brukseli, która jest największą światową organizacją zrzeszająca dziennikarzy. Została ona założona w 1926 toku, odnowiła swoją działalność w 1946 roku, a w obecnej formie działa od 1952 roku. Dzisiaj federacja skupia około 600000 członków z ponad 100 krajów. IFJ promuje prawa człowieka, demokrację i pluralizm oraz jest przeciwna wszelkim środkom dyskryminacji oraz potępia używanie środków przekazu jako propagandy lub do szerzenia nietolerancji i konfliktu. IFJ jest organizacją, która reprezentuje dziennikarzy na forum Organizacji Narodów Zjednoczonych $^{1}$. IFJ monitoruje naruszenia wolności prasy, a także prowadzi kampanie dla zwiększenia bezpieczeństwa dziennikarzy i wolnych strzelców, którzy są narażeni na największe ryzyko i mają jednocześnie najsłabszą ochronę. Wszelkie działania IFJ są prowadzone wspólnie z członkami związku na całym świecie oraz z innymi organizacjami dzięki IFEX - The International Freedom of Expression Exchange. IFJ wydaje także legitymacje, które są najwyżej cenione przez korespondentów wojennych. Federacja jest także założycielem The International News Safety Institute, który powstał w 2003 roku i promuje praktyczne działania dla zwiększenia bezpieczeństwa i ochrony dziennikarzy oraz mediów ${ }^{2}$. IFJ powołał także International Safety Fund, który zapewnia humanitarną pomoc dziennikarzom, będącym w potrzebie ${ }^{3}$.

1 http://www.ifj.org/en/pages/about-ifj z 5.06.2008.

2 Strona oficjalna The International Federation of Journalists http://www.ifj.org/en/pages/press-freedom-safety z 5.06.2008.

3 http://www.ifj.org/en/pages/about-ifj. 
Jednak szczególnym poważaniem z uwagi na swą działalność cieszy się także The Committee to Protect Journalists (CPJ) ${ }^{4}$. CPJ jest znany ze swych statystyk, bowiem stosując ścisłe dziennikarskie standardy, bada przyczyny śmierci żurnalistów. Organizacja postrzega za przypadek potwierdzony, tylko taką śmierć, kiedy jest rozsądnie pewna, że dziennikarz został zabity w bezpośrednim odwecie za wykonywaną przez niego pracę, lub wtedy gdy wykonywał niebezpieczne zadanie związane ze swoją pracą. Statystyki CPJ nie dotyczą dziennikarzy, którzy zostali zabici w wypadkach samochodowych lub samolotowych, chyba że wypadek został spowodowany przez wrogie działanie (na przykład, jeżeli samolot został trafiony czy też samochód został rozbity). CPJ zawiera w swojej bazie danych i analizach statystycznych tylko potwierdzone przypadki śmierci w związku z wykonywanym zawodem. Jeżeli motywy są niejasne, ale jest możliwe, że dziennikarz został zabity z powodu swojej pracy, CPJ klasyfikuje taki przypadek jako ,niepotwierdzony” i kontynuuje dochodzenie określenia motywów morderstwa ${ }^{5}$. Dane są uaktualniane kwartalnie i opisują kto jest zabijany, jak, dlaczego i gdzie. Poniżej została przedstawiona zbiorcza statystyka:

Tabela 1

Dziennikarze zabici w okresie od 1 stycznia 1992 roku do 11 października 2008 roku Ogólna liczba - 685

\begin{tabular}{|c|c|c|}
\hline Kto & Jak & Podejrzani o morderstwo \\
\hline 1 & 2 & 3 \\
\hline $\begin{array}{l}\text { Praca: } \\
\text { reporterzy prasowi/pisarze: } 31,6 \% \\
\text { reporterzy radiowi i telewizyjni: } 20,9 \% \\
\text { redaktorzy: } 16,1 \% \\
\text { operatorzy kamer: } 9,8 \% \\
\text { felietoniści/komentatorzy: } 9,1 \% \\
\text { fotografowie: } 7,9 \% \\
\text { producenci: } 5,8 \% \\
\text { wydawcy/właściciele: } 3,9 \% \\
\text { pracownicy techniczni: } 2,2 \%\end{array}$ & \begin{tabular}{|l|} 
Rodzaj śmierci: \\
Morderstwa: $72,1 \%$ \\
ogień krzyżowy/walki: $17, \%$ \\
podczas innych niebez- \\
$\quad$ piecznych: $10,2 \%$ \\
nieokreslone: $0,2 \%$ \\
Rodzaj użytej broni: \\
mała broń (włączając pisto- \\
lety, karabiny): $53 \%$ \\
broń cieżka (właczajac arty-
\end{tabular} & $\begin{array}{l}\text { Podejrzani sprawcy mor- } \\
\text { derstw: } \\
\text { grupy polityczne: } 31,2 \% \\
\text { oficjalny rząd: } 18,5 \% \\
\text { grupy kryminalne: } 11,1 \% \\
\text { grupy paramilitarne: } 7,2 \% \\
\text { wojsko: } 5,8 \% \\
\text { lokalni mieszkańcy: } 2,1 \% \\
\text { tłum: } 1,2 \% \\
\text { nieznani: } 22 \%\end{array}$ \\
\hline $\begin{array}{l}\text { Środek przekazu: } \\
\text { drukowane: } 56,8 \% \\
\text { telewizja: } 26,9 \%\end{array}$ & $\begin{array}{l}\text { lerię, atak powietrzny): } \\
14,3 \% \\
\text { wybuchy: } 10,5 \%\end{array}$ & $\begin{array}{l}\text { Bezkarność } \mathbf{w} \text { przypad- } \\
\text { kach zabójstw: } \\
\text { całkowita bezkarność: } 88,5 \%\end{array}$ \\
\hline
\end{tabular}

4 P. Grochmalski, Praca dziennikarza w warunkach wojny, „Problemy Humanistyki”. Zeszyty naukowe WSNHiD, Poznań 1999, s. 76; zob. szerzej na http://www.ifj.org.

5 http://www.cpj.org/deadly/index.html z 22.05.2008. 


\begin{tabular}{|c|c|c|}
\hline 1 & 2 & 3 \\
\hline $\begin{array}{l}\text { radio: } 19,2 \% \\
\text { Internet: } 1,8 \% \\
\text { Pleć: } \\
\text { mężczyzna: } 93,1 \% \\
\text { kobieta: } 6,9 \% \\
\text { Miejscowi/obcokrajowy: } \\
\text { miejscowi: } 86 \% \\
\text { korespondenci zagraniczni: } 14 \% \\
\text { Wolni strzelcy: } 11,6 \%\end{array}$ & $\begin{array}{l}\text { nóż: } 6,6 \% \\
\text { walka wręcz (włączając bi- } \\
\text { cie i duszenie): } 5 \%\end{array}$ & $\begin{array}{l}\text { częściowa sprawiedliwość: } \\
6,4 \% \\
\text { całkowita sprawiedliwość: } \\
5,1 \% \\
\text { Zagrożony przed morder- } \\
\text { stwem: } 28,8 \% \\
\text { Pojmany przed morder- } \\
\text { swem: } 18,7 \%\end{array}$ \\
\hline Gdzie & Kiedy & Dlaczego \\
\hline $\begin{array}{l}\text { 20 najniebezpieczniejszych krajów: } \\
\text { 1. Irak: } 135 \\
\text { 2. Algieria: } 60 \\
\text { 3. Rosja: } 49 \\
\text { 4. Kolumbia: } 40 \\
\text { 5. Filipiny: } 34 \\
\text { 6. Indie: } 24 \\
\text { 7. Somalia: } 23 \\
\text { 8. Pakistan: } 20 \\
\text { 9. Bośnia: } 19 \\
\text { 10. Turcja: } 20 \\
\text { 11. Afganistan: } 17 \\
\text { 12. Rwanda: } 16 \\
\text { 13. Sierra Leone: } 16 \\
\text { 14. Tadżykistan: } 16 \\
\text { 15. Brazylia: } 15 \\
\text { 16. Sri Lanka: } 16 \\
\text { 17. Meksyk: } 14 \\
\text { 18. Bangladesz: } 12 \\
\text { 19. Izrael: } 9 \\
\text { 20. Angola: } 8 \\
\text { 21. Kambodża: } 8 \\
\text { 22. Gruzja: } 8 \\
\text { 23. Jugosławia: } 8\end{array}$ & $\begin{array}{l}\text { 2008 (do 14.10.): } 33 \\
\text { 2007: } 65 \\
\text { 2006: } 56 \\
\text { 2005: } 48 \\
\text { 2004: } 60 \\
\text { 2003: } 41 \\
\text { 2002: } 21 \\
\text { 2001: } 37 \\
\text { 2000: } 24 \\
\text { 1999: } 36 \\
\text { 1998: } 24 \\
\text { 1997: } 26 \\
\text { 1996: } 26 \\
\text { 1995: } 51 \\
\text { 1994: } 66 \\
\text { 1993: } 57 \\
\text { 1992: } 42\end{array}$ & $\begin{array}{l}\text { Tematyka podejmowana } \\
\text { przez ofiary: } \\
\text { wojna: } 33,7 \% \\
\text { polityka: } 26,1 \% \\
\text { korupcja: } 20,1 \% \\
\text { prawa człowieka: } 12,6 \% \\
\text { przestępczośc: } 12,8 \% \\
\text { sport/kultura: } 5,3 \% \\
\text { biznes: } 1,7 \%\end{array}$ \\
\hline
\end{tabular}

Źródło: http://www.cpj.org/deadly/index.html z 30.12.2008.

CPJ wydała także Przewodnik dla Relacjonowania w Sytuacjach Niebezpiecznych (A Guide to Reporting in Dangerous Situations), który zawiera komponenty, takie jak: szkolenia, sprzęt ochronny, ubezpieczenie zdrowotne, środki ostrożności dla zdrowia, znajomość punktów zapalnych na świecie, pozostawanie w kontakcie, minimalizowanie ryzyka w strefie konfliktu, wybory dokonywane na polu walki, reguły wojny, sytuacje pojmania, reakcje na stres, powszechne zagrożenie, oszacowanie 
indywidualnego ryzyka, plany awaryjne, wolni strzelcy i ustalenia, inne opcje, sugerowane artykuły, środki wsparcia, kredyt i uznanie ${ }^{6}$.

Znany ze swej działalności jest także Word Press Freedom Committee (WPFC), zrzeszający ponad czterdzieści organizacji broniących wolności słowa, który w 1987 roku, w Londynie przyjął Kartę Wolności Mediów. Dziesiąty punkt Karty stwierdza, że ,dziennikarze na równi z wszystkimi obywatelami muszą mieć zapewnione bezpieczeństwo osobiste i być otoczeni pełną ochroną ze strony prawa. Dziennikarzy pracujących w strefach działań wojennych uważa się za osoby cywilne, korzystające z wszelkich praw i nietykalności przysługującej innym osobom cywilnym" ${ }^{\text {"7 }}$. Niestety pomimo faktu, iż formalnego poparcia dla Karty udzielił Sekretarz Generalny ONZ oraz Dyrektor Generalny UNESCO, jej przepisy są tylko martwą literą prawa, teoretycznie chroniącą dziennikarzy.

Inną organizacją, zajmującą się tą tematyka jest International Press Institute (IPI). IPI jest organizacją międzynarodową, która rozpoczęła swoją działalność w 1950 roku, a jej głównym celem była walka o wolność prasy oraz promocja wysokich standardów dziennikarskich. Dziś jest organizacją, zrzeszającą szefów mediów, wydawców i dziennikarzy. IPI stale działa na rzecz wzmocnienia i zachowania wolności prasy, ochrony swobody wypowiedzi, promowania swobodnego przepływu informacji, podniesienia standardów dziennikarskich oraz ochrony dziennikarzy pracujących w zapalnych regionach ${ }^{8}$. IPI każdego roku wydaje ,World Review Freedom Press", który bada stan mediów w ponad 180 krajach, terenach i obszarach zarządzanych, udokumentowując pogwałcenie wolności prasy oraz rozwój mediów na całym świecie. „World Review Freedom Press” jest podzielony na określone regiony, a każde sprawozdanie określa wszechstronny przegląd wydarzeń roku i może zostać porównane z wydarzeniami z poprzednich lat ${ }^{9}$. IPI organizuje także kongresy, które są doskonałą możliwością konfrontacji poglądów oraz dyskusji na palące tematy. Na przykład 12 maja 2002 roku podczas kongresu w stolicy Słowenii Lublanie odbyła się sesja na temat Protection of Jurnalists in Regions of Conflicts, na której światowej sławy dziennikarze podjęli temat ochrony

6 Zob. więcej na: http://www.cpj.org/Briefings/2003/safety/journo_safe_guide.pdf z 22.05.2008.

7 Zalety i tajniki dziennikarstwa. Podręcznik dla dziennikarzy Europy Środkowej $i$ Wschodniej, pod red. M. F. Mallette, s. 237. Tekst Karty w wersji angielskiej dostępny na stronie http://wpfc.org/CharterForAFreePress.html.

${ }^{8}$ http://wyborcza.pl/1,79328,4054551.html z 22.05.2008.

9 http://freemedia.at/cms/ipi/freedom.html z 22.05.2008. 
i bezpieczeństwa żurnalistów w strefach konfliktów zbrojnych. Zwrócono uwagę na fakt, iż należy dążyć do jak największego jednolitego wyróżnienia dziennikarzy, tak by byli oni jednoznacznie utożsamiani tylko z mediami i nie stawali się potencjalnym celem dla stron walczących. Podjęto temat odpowiedniego przygotowania i ubezpieczenia korespondentów. Naświetlono sprawę bezkarności represji i mordowania dziennikarzy, niepodejmowania odpowiednich działań ze strony władz oraz kwestię uwikłania najwyższych przedstawicieli wielu krajów w działania przeciwko dziennikarzom ${ }^{10}$. Innym przykładem działalności IPI jest także uchwalenie 12 maja 2007 roku Rezolucji o porywaniu dziennikarzy, gdzie stwierdza się, że porwania zniechęcają dziennikarzy do informowania, co ogranicza dostęp społeczeństwa do informacji. Skutkiem tego jest dość częsta próżnia, w której nad dokładną i uczciwą informacją dominuje pogłoska i domniemanie. IPI wierzy, że porywanie dziennikarzy nie pomaga sprawie porywaczy. IPI potępia wszystkich tych, którzy porywają dziennikarzy i nawołuje ich do uszanowania niezależności mediów i uwalniania ich natychmiast ${ }^{11}$.

Swojej pomocy udziela reporterom także organizacja Reporterzy bez Granic (RWB, RSF), która została założona w 1985 roku. RWB jest organizacją non-profit i posiada status doradcy przy Organizacji Narodów Zjednoczonych. Jej głównym celem jest walka o wolność prasy. RWB broni dziennikarzy i pomocników medialnych uwięzionych lub prześladowanych z powodu wykonywania zawodu oraz ujawnia ich nieludzkie traktowanie i torturowanie w wielu krajach, sprzeciwia się cenzurze i prawu, które osłabia zasadę wolnej prasy, pomaga finansowo dziennikarzom lub punktom medialnym w trudnościach (płaci za prawników, opiekę medyczną i wyposażenie) oraz rodzinom uwięzionych dziennikarzy, działa w zakresie poprawy bezpieczeństwa dziennikarzy, działających w strefach konfliktów zbrojnych. Organizacja wydaje codzienne komunikaty i regularne publikacje. Ponadto każdego roku, w styczniu organizacja podsumowuje rok i wydaje „Przegląd Wolności Prasy” na świecie, gdzie przedstawia liczbę dziennikarzy zabitych, zatrzymanych, zagrożonych,

10 R. Święs, Bezpieczeństwo dziennikarzy w rejonach konfliktów zbrojnych. Sytuacja prawna, problemy, statystyki, w: Wojna. Doświadczenie i zapis. Nowe źródła, problemy, metody badawcze, pod red. S. Buryła, P. Rodak, Kraków 2006, s. 275-277.

11 IPI Resolution on the Kidnapping of Journalists. 12.05.2007, http://www.freemedia.at/cms/ipi/statements_detail.html?ctxid=CH0055\&docid=CMS1178978570567 z 22.05.2008. 
fizycznie atakowanych i ocenzurowane media. Ponadto 3 maja, czyli w Światowym Dniu Wolności Prasy, RWB publikuję listę prześladowców wolnej prasy. Z kolei „Światowy Wskaźnik Wolnej Prasy” jest wydawany w październiku i ukazuje stopień wolności prasy i mediów ${ }^{12}$.

Na przykład „Przegląd Wolności Prasy” za rok 2007 wskazuje, iż zostało zabitych 86 dziennikarzy, czyli wskaźnik śmiertelności dziennikarzy wzrósł o $244 \%$ w ciągu pięciu lat.

W 2007 roku:

- 86 dziennikarzy oraz 20 pracowników medialnych zostało zabitych,

- 887 zostało aresztowanych,

- 1511 fizycznie zaatakowanych oraz zastraszonych,

- 67 dziennikarzy zostało porwanych,

- 528 punktów medialnych zostało ocenzurowanych.

Należy zauważyć, iż większa połowa dziennikarzy zginęła w Iraku ${ }^{13}$.

Dla porównania w roku 2008:

- 60 dziennikarzy oraz 1 pracownik medialny zostało zabitych,

- 673 zostało aresztowanych,

- 929 zostało fizycznie zaatakowanych oraz zastraszonych,

- 29 zostało porwanych,

- 353 punkty medialne zostało ocenzurowane ${ }^{14}$.

Natomiast wskaźnik śmiertelności dziennikarzy za dwa ostatnie lata przedstawia się w następujący sposób:

Tabela 2

Wskaźnik śmiertelności dziennikarzy w roku 2007

\begin{tabular}{|l|r|r|c|c|c|}
\hline \multicolumn{1}{|c|}{$\mathbf{2 0 0 7}$} & Zabici & $\begin{array}{c}\text { Aresz- } \\
\text { towani }\end{array}$ & $\begin{array}{c}\text { Fizycznie } \\
\text { zaatakowani } \\
\text { i zagrożeni }\end{array}$ & $\begin{array}{c}\text { Ocenzurowa- } \\
\text { ne punkty } \\
\text { medialne }\end{array}$ & Porwani \\
\hline Afryka & 12 & 162 & 145 & 61 & 1 \\
\hline Ameryki & 7 & 86 & 626 & 91 & 11 \\
\hline Azja & 17 & 430 & 562 & 273 & 23 \\
\hline Europa + były sowiecki blok & 2 & 77 & 83 & 60 & 3 \\
\hline Pólnocna Afryka + Bliski Wschód & 48 & 132 & 95 & 43 & 29 \\
\hline Ogólem & $\mathbf{8 6}$ & $\mathbf{8 8 7}$ & $\mathbf{1 5 1 1}$ & $\mathbf{5 2 8}$ & $\mathbf{6 7}$ \\
\hline
\end{tabular}

Źródło: http://www.rsf.org/article.php3?id_article=24909 z 23.05.2008.

12 http://www.rsf.org/rubrique.php3?id_rubrique=280 z 30.12.2008.

$13 \mathrm{http}: / /$ www.rsf.org/article.php3?id_article=24909 z 30.12.2008.

$14 \mathrm{http}: / /$ www.rsf.org/article.php3?id_article=29797 z 4.022009. 
Stąd ogólna mapa zabitych dziennikarzy w roku 2007 prezentuje się w następujący sposób:

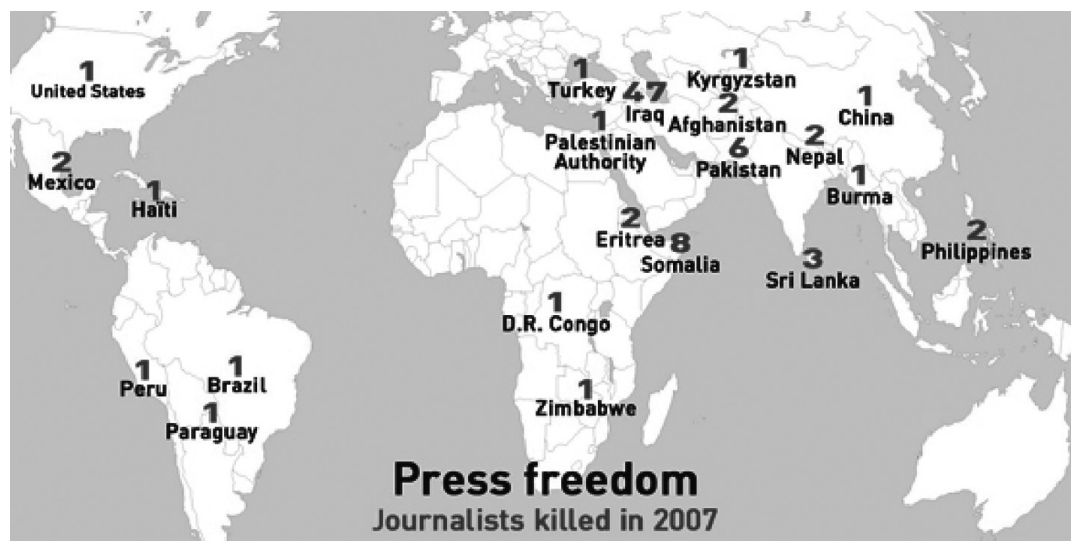

Mapa 1. Mapa zabitych dziennikarzy

Źródlo: http://www.rsf.org/article.php3?id_article=24909 z 30.12.2008.

Z kolei Wskaźnik śmiertelności dziennikarzy w roku 2008 przedstawia tabela poniżej.

Tabela 3

Wskaźnik śmiertelności dziennikarzy w roku 2008

\begin{tabular}{||l|r|r|c|c|c||}
\hline \multicolumn{1}{|c|}{2008} & Zabici & $\begin{array}{c}\text { Aresz- } \\
\text { towani }\end{array}$ & $\begin{array}{c}\text { Fizycznie } \\
\text { zaatakowani } \\
\text { i zagrożeni }\end{array}$ & $\begin{array}{c}\text { Ocenzuro- } \\
\text { wane punkty } \\
\text { medialne }\end{array}$ & Porwani \\
\hline Afryka & 3 & 263 & 117 & 41 & 9 \\
\hline Azja/Pacyfik & 26 & 60 & 106 & 70 & 0 \\
\hline Ameryki & 7 & 127 & 414 & 72 & 16 \\
\hline Europa + były sowiecki blok & 8 & 86 & 168 & 79 & 0 \\
\hline $\begin{array}{l}\text { Pólnocno-zachodnia Afryka } \\
\text { + Bliski Wschód }\end{array}$ & 16 & 137 & 124 & 91 & 4 \\
\hline Ogólem & $\mathbf{6 0}$ & $\mathbf{6 7 3}$ & $\mathbf{9 2 9}$ & $\mathbf{3 5 3}$ & $\mathbf{2 9}$ \\
\hline
\end{tabular}

Źródło: http://www.rsf.org/article.php3?id_article=29797 z 4.02.2009.

RWB zwraca szczególną uwagę na fakt, iż każdego roku, kilkudziesięciu dziennikarzy jest zabijanych podczas informowania opinii publicznej o działaniach wojennych, a wojna w Iraku, będąc najbardziej krwawym 
konfliktem od czasów II wojny światowej, pokazuje tylko jak ważna jest ochrona osób, pracujących $\mathrm{w}$ tak trudnych warunkach. RWB oferują dziennikarzom prawną i rzeczową pomoc, taką jak: Praktyczny Przewodnik, Kartę Bezpieczeństwa, kursy szkoleniowe i inne udogodnienia, jak również wyposażenie dla własnego bezpieczeństwa: kuloodporne kurtki, hełmy, apteczkę pierwszej pomocy oraz oferuje gorącą linię w przypadku kłopotów na polu walki ${ }^{15}$. RWB zapewnia ubezpieczenie dla wolnych strzelców, którzy coraz częściej wyjeżdżają na konflikt zbrojny bez jego posiadania, z powodu wysokich kosztów i braku informacji na jego temat ${ }^{16}$. Organizacja wypożycza dziennikarzom kuloodporne kurtki oraz hełmy za darmo. Kurtki są koloru czarnego i posiadają z przodu oraz na plecach napis „PRESS”. Hełmy z kolei są białe z napisem „TV”. Ponadto można również wypożyczyć małe, świecące indywidualne GPS-y ${ }^{17}$. RWB oferują wolnym strzelcom apteczkę pierwszej pomocy, jeśli jest im niezbędna ${ }^{18}$.

Działa także gorąca linia, dostępna pod numerem telefonu 1 4777-7414, czynna każdego dnia, o każdej porze ${ }^{19}$.

Reporterzy bez Granic wydają również praktyczny przewodnik dla reporterów, którzy wybierają się w niebezpieczne regiony. Radzi on jak należy się zachować podczas ostrzału czy przejazdu przez punkt kontrol$n y^{20}$. Ów 52-stronicowy Practical guide for journalists zawiera podstawowe dokumenty, uznające wolność prasy, odniesienia do dokumentów o profesjonalnej etyce, wytyczne dla indywidualnej i wspólnej opieki dziennikarzy śledczych, procedury ochrony dziennikarzy i innych pracowników, procedury pierwszej pomocy, wytyczne i procedury dochodzenia naruszeń wolności prasy, pisanie raportów z dochodzenia, relacje z ICRC (The International Committee of the Red Cross) oraz innymi organizacjami pozarządowymi, pomocne adresy, kilka ogólników na temat Reporterów bez Granic, wskazówki o gorącej linii, ogólniki o wolności prasy na świecie oraz Kartę Bezpieczeństwa Dziennikarzy Pracujących w Strefach Wojny lub Niebezpiecznych Obszarach ${ }^{21}$. Karta Bezpieczeń-

15 http://www.rsf.org/rubrique.php3?id_rubrique $=692 \mathrm{z}$ 23.05.2008.

$16 \mathrm{http}: / /$ www.rsf.org/article.php3?id_article=21746 z 23.05.2008.

$17 \mathrm{http}: / /$ www.rsf.org/article.php3?id_article=21747 z 23.05.2008.

$18 \mathrm{http}: / /$ www.rsf.org/article.php3?id_article=21748 z 23.05.2008.

$19 \mathrm{http}: / /$ www.rsf.org/article.php3?id_article=21749 z 23.05.2008.

20 J. Przybylski, op. cit.

21 Charter for the Safety of Journalists Working in War Jones or Dangerous Areas, http://www.rsf.org/IMG/doc-1353.pdf z 22.05.2008. 
stwa zawiera osiem zasad, które w przypadku ich zastosowania przez kierownictwo mediów, mogą pomóc w zapobieganiu lub zminimalizowaniu niebezpieczeństw, z jakimi spotykają się dziennikarze, pracujący w terenach niebezpiecznych. Karta stanowi: „Bezpieczeństwo dziennikarzy pracujących przy niebezpiecznych zadaniach nie jest zawsze zagwarantowane, nawet kiedy prawo międzynarodowe daje właściwe zabezpieczenie na papierze, gdyż walczące strony okazują coraz mniej respektu dla prawa. Dziennikarze nie mogą zdobyć zapewnienia od stron walczących, że będą w pełni chronieni. Ze względu na ryzyko, jakie ponoszą, po to, by móc informować opinię publiczną, pracownicy mediów, dziennikarze i ich pomocnicy (ci na etacie i wolni strzelcy), pracujący w rejonach wojen lub niebezpiecznych terenach, są uprawnieni do podstawowej ochrony, uposażeń i odszkodowań ze strony ich pracodawców. Jednak ochrona nigdy nie może oznaczać nadzoru ze strony lokalnych władz wojskowych lub państwowych. Kierownictwa mediów są również odpowiedzialne za podjęcie każdego możliwego wysiłku, by zapobiec i zredukować związane z zadaniem niebezpieczeństwa"22. Karta wymienia zasadę zobowiązania (odpowiedniego przygotowania, informacji, ubezpieczenia i wyposażenia), wolnej woli (poświęcenie obsługi wojen wymaga dobrowolności decyzji), przygotowania (pracownicy powinni być dojrzali i przyzwyczajeni do sytuacji kryzysowych), przygotowania w sensie regularnych szkoleń w zakresie radzenia sobie w strefach wojen i rejonach niebezpiecznych, wyposażenia (niezawodny sprzęt zapewniający bezpieczeństwo, sprzęt do komunikowania, ekwipunek do przeżycia i pierwszej pomocy), ubezpieczenia (od chorób, repatriacji, kalectwa, śmierci), poradnictwa psychologicznego (dostęp do doradcy psychologicznego po powrocie z terenów niebezpiecznych lub objętych wstrząsającymi wydarzeniami) oraz zasadę ochrony prawnej, która głosi: „Dziennikarze obsługujący niebezpieczne zadania są uważani za cywili w myśl artykułu 79, I Protokołu Dodatkowego do konwencji genewskich, pod warunkiem że nie robią niczego, co mogłoby być sprzeczne z tym statusem, jak udział w walce, posiadanie broni lub szpiegowanie. Jakikolwiek zamierzony atak na dziennikarzy, który spowoduje śmierć lub poważne obrażenia, jest poważnym gwałceniem tego Protokołu i uznawany jest za zbrodnię wojenną",23.

22 Tłum. Za: R. Święs, op. cit., s. 278-279.

23 Zob. szerzej w: R. Święs, op. cit., s. 279; A Charter for the Safety of Journalists Working in War Zones or Dangerous Areas, sporządzona przez Reporters Without 
Niestety Karta jest dokumentem organizacji pozarządowej, a co za tym idzie siła jej oddziaływania i skuteczność nie jest przesadnie wielka. Jest to raczej zbiór postulatów i zasad etycznych. Ponadto postanowienia Karty nakładają obowiązki nie tyle na państwa, strony konfliktu, ale na samych dziennikarzy i redakcje ich zatrudniające. Zatem wyegzekwowanie od pracodawców, przestrzegania postanowień Karty może okazać się niemożliwe. Sama Karta jest jednak kolejnym krokiem, podejmowanym w celu zabezpieczenia losu korespondentów wojennych i jako taka powinna być brana pod uwagę przy podejmowaniu dalszych prac legislacyjnych zmierzających do uregulowania statusu dziennikarzy pracujących w strefach niebezpiecznych i regionach konfliktów zbrojnych ${ }^{24}$.

Ze swej krótkiej, ale intensywnej działalności powszechnie znany jest także The International Covenant for the Protection of Journalists (ICPJ) - Międzynarodowe Porozumienie dla Ochrony Dziennikarzy, które zostało utworzone 10 września 2007 roku, kiedy to stowarzyszenia mediów spotkały się w Genewie i przyjęły za swój cel opracowanie wyspecjalizowanej konwencji dla ochrony mediów w strefach konfliktów albo gdziekolwiek indziej. ICPJ wspiera stowarzyszenia mediów i dziennikarzy, którzy stawiają czoło wszelakim przymusom podczas pełnienia czynności zawodowych, czy to podczas konfliktów zbrojnych, czy rozruchów społecznych albo innych globalnych wydarzeń, które prowadzą do aktów przemocy poprzez zmuszanie do przywrócenia porządku i prawa ${ }^{25}$. ICPJ udziela także poparcia The Press Emblem Campaign - PEC, czyli Kampanii Emblematu Prasy ${ }^{26}$.

Borders w 2002 dostępna jest na stronie: http://www.rsf.org/IMG/pdf/charter_en.pdf z 23.05.2008. Jacek Sobczak zauważa, iż sformułowanie o zbrodni wojennej wydaje się być dalekie od ścisłości. J. Sobczak, Korespondent wojenny-ramy prawne i praktyka, w: Wojna. Doświadczenie i zapis. Nowe źródta, problemy, metody badawcze, pod red. S. Buryła, P. Rodak, Kraków 2006, s. 262.

24 J. Sobczak, Korespondent..., s. 263.

25 Oficjalna strona International Covenant for the Protection of Journalists (ICPJ), http://www.mediacovenant.org/5664.html z 5.05.2008.

26 The Press Emblem Campaign jest globalnym stowarzyszeniem założonym przez dziennikarzy. PEC została założona w czerwcu 2004 roku przez grupę dziennikarzy z kilku krajów w Genewie. Jest niezależną organizacją non-profit, a jej celem jest umocnienie prawnej ochrony i bezpieczeństwa dziennikarzy w strefach konfliktów zbrojnych i społecznych zamieszek poprzez przyjęcie nowej międzynarodowej konwencji. Oficjalna strona The Press Emblem Campaign http://www.pressemblem.ch/4597.html z 30.12.2008. 
W dniu 26 listopada 2007 roku, ponad stu reprezentantów państw, organizacje Międzynarodowego Czerwonego Krzyża i Czerwonego Półksiężyca, organizacje medialne zgromadziły się w Genewie, gdzie odbyła się konferencja, na której rozważano stosowność prawa wojennego w stosunku do mediów i dyskutowano o możliwościach poprawy bezpieczeństwa medialnego personelu. Spotkanie zostało zorganizowane pod auspicjami Międzynarodowego Czerwonego Krzyża i poprzedziło otwarcie 30-stej Międzynarodowej Konferencji Czerwonego Krzyża i Czerwonego Półksiężyca $^{27}$. Podczas spotkania, stowarzyszenia medialne zaproponowały tekst międzynarodowej konwencji o wzmocnieniu ochrony dziennikarzy podczas trwania konfliktów zbrojnych i w innych sytuacjach. Propozycja tej międzynarodowej Konwencji została poddana ogólnoświatowej konsultacji ${ }^{28}$.

Propozycja Konwencji międzynarodowej o polepszeniu ochrony dziennikarzy w konfliktach zbrojnych i innych sytuacjach, przypomniała zobowiązania Państw Stron, wobec Karty Narodów Zjednoczonych dla wspierania powszechnego poszanowania oraz przestrzegania praw człowieka i podstawowych wolności. Potwierdzono w niej art. 19 Powszechnej Deklaracji Praw Człowieka, przyjętej 10 grudnia 1948 roku, który stwierdza, że „Każdy człowiek ma prawo wolności opinii i wyrażania jej; prawo to obejmuje swobodę posiadania niezależnej opinii, poszukiwania, otrzymywania i rozpowszechniania informacji i poglądów wszelkimi środkami bez względu na granice" oraz art. 19 Międzynarodowego Paktu Praw Obywatelskich i Politycznych z 16 grudnia 1966 r. (Dz. U. 1977, Nr 38, poz. 167), który zakłada, że „Każdy człowiek ma prawo posiadania bez przeszkód własnych poglądów” (art. 19.1) oraz „Każdy człowiek ma prawo do swobodnego wyrażania opinii; prawo to obejmuje swobodę poszukiwania, otrzymywania i rozpowszechniania wszelkich informacji i poglądów, bez względu na granice państwowe, ustnie, pismem lub drukiem, w postaci dzieła sztuki bądź w jakikolwiek inny sposób według własnego wyboru" (art. 19.2). Przywołano Rezolucję 1738, przyjętą przez

27 Covering war and disaster, Report on special meeting on media safety and IHL in war reporting, Geneva 26.11.2007, http:/www.icrc.org/web/eng/siteeng0.nsf/html/media-ihl-report-261107 z 5.06.2008.

28 Draft proposal for an International Convention to strengthen the protection of journalists in armed conflicts and other situations, dostępna na stronie http://www.mediacovenant.org/32301.html z 5.05.20068 oraz na http://www.pressemblem.ch/4983.html z 5.05.2008. 
Radę Bezpieczeństwa Organizacji Narodów Zjednoczonych z 23 grudnia 2006 roku, która potępia zamierzone ataki przeciwko dziennikarzom, profesjonalistom mediów i stowarzyszonym pracownikom, w sytuacjach konfliktu zbrojnego, nawołującą wszystkie strony, aby położyć kres takim praktykom. Przywołano także debaty Zgromadzenia Ogólnego Narodów Zjednoczonych, rozpoczęte na dwudziestej piątej sesji w 1970 roku, propozycję międzynarodowej konwencji o ochronie dziennikarzy w niebezpiecznych misjach zawodowych, która została przedłożona pod dyskusję na dwudziestej ósmej sesji oraz Rezolucję 3059, przyjętą 2 czerwca 1973 roku, wyrażającą opinię, że wskazane będzie przyjęcie konwencji o ochronie dziennikarzy, pełniących niebezpieczne, zawodowe misje. Przypomniano, że zgodnie z Konwencjami genewskimi z 12 sierpnia 1949 roku oraz Protokołami dodatkowymi z 8 czerwca 1977 roku, zamierzone ataki na osoby cywilne są zabronione. Potwierdzono art. 79 Protokołu do Konwencji Genewskich z 12 sierpnia 1949 roku, dotyczącego ochrony ofiar międzynarodowych konfliktów zbrojnych (I Protokół) z 8 czerwca 1977 roku, który stwierdza: „Dziennikarze, którzy spełniaja niebezpieczne misje zawodowe w strefach konfliktu zbrojnego, będą traktowani jak osoby cywilne w rozumieniu ustępu 1 artykułu 50”. „Będą oni ochraniani jako tacy, stosownie do Konwencji i niniejszego protokołu, pod warunkiem niepodejmowania żadnego działania, które byłoby sprzeczne z ich statusem osób cywilnych". Zauważono, że doświadczenia pokazuja, iż od czasu przyjęcia I Protokołu, postanowienia art. 79 są rzadko respektowane i ochrona, którą objęci są z założenia dziennikarze, jest raczej nieefektywna. W związku z tym Państwa Strony uznały, że wzrastająca liczba ataków przeciwko dziennikarzom, skierowane przeciwko nim zabójstwa i porwania, zmieniły specyfikę zawodu, co powoduje, że art. 79 jest nieadekwatny do obecnych okoliczności. Jest to problem globalny z powodu zabitych dziennikarzy w różnych regionach świata. W propozycji Konwencji wyrażono głębokie zaniepokojenie wysokim wskaźnikiem aktów przemocy w stosunku do dziennikarzy, stowarzyszonych pracowników i medialnych profesjonalistów, pomimo ich statusu osób cywilnych. Stwierdzono, że ataki przeciwko dziennikarzom mają miejsce nie tylko podczas międzynarodowych konfliktów zbrojnych, ale także podczas zamieszek społecznych i innych sytuacji przemocy, niepokojów, rozruchów czy protestów. Dlatego zadecydowano zapobiegać atakom na dziennikarzy, zwalczać bezkarność i zapewnić prawo ofiar do sprawiedliwości i odszkodowania. Uznano przy tym istotną rolę dziennikarzy i profesjonalistów medialnych, w poświadczaniu i czynieniu jawnym 
wszelkich naruszeń praw człowieka i prawa humanitarnego oraz wskazano, że należy oskarżyć tych, którzy dokonali aktów naruszeń i zapewnić uszanowanie prawa osób cywilnych przez wszystkie Strony. Podkreślono konieczność lepszego rozróżnienia dziennikarzy od walczących oraz innych osób cywilnych, a także zwrócono uwagę na świadomość powagi ryzyka w strefach konfliktów zbrojnych, gdzie dziennikarze oraz profesjonaliści medialni przebywają podczas zbierania informacji, fotografii, filmów, nagrań audio albo innych dokumentacji oraz rozpowszechniania ich i uznano, że korespondenci potrzebują zwiększonej ochrony w porównaniu z innymi cywilami. Ponadto Państwa - Strony:

- mając na uwadze zmieniającą się naturę nowoczesnych działań wojennych w XXI wieku, która nie odróżnia cywilnego od militarnego celu, cywila od zamachowcy samobójcy;

- zauważając, że technologiczne postępy w militarnej technologii i informacyjne technologie medialne umożliwiły rozprzestrzenianie się mediów na obszarach działań wojskowych bez osłony;

- podkreślając, że ten rodzaj działań wojennych oraz zaangażowanie aktorów spoza Stron, czyni bardzo trudnym, opisywanie wydarzeń z oddali, ale ułatwia dostęp zamachowcom samobójcom;

- odnotowując, że ten rozwój zwiększa niebezpieczeństwa, stojące przed zawodem medialnym w konfliktach zbrojnych i gdzie indziej, tam gdzie ludzie są zdecydowani zaatakować, czy to jednostki, likwidując fizycznie członków środków przekazu, czy to powodując eksplozje na skalę masową;

- biorąc pod uwagę fakt, że jasne przykłady takich ataków mają miejsce tam, gdzie pojęcie prawa i porządku zniknęło albo w innych okolicznościach, gdzie podmiot jest likwidowany, aby udaremnić prawo wyrażania oraz opinii albo w odosobnionych przypadkach, kiedy zamachowcy samobójcy reprezentują regularną armię;

- podkreślając, że ogólna ochrona zgodnie z prawem humanitarnym o ludności cywilnej będzie wzmocniona przez częstszą obecność dziennikarzy na obszarze obok ofiar;

- potwierdzając, że wolność prasy i wolne uprawianie dziennikarstwa jest istotne dla zapewnienia prawa do publicznego informowania we wszystkich okolicznościach;

- uznając, że niebezpieczeństwo wzrosło, szczególnie z powodu szybkiego wzrostu liczby aktorów na obszarach, włączając liczne zbrojne grupy spoza Stron, spośród których kilka zajmuje się otwarcie aktami terroryzmu; 
- uzgadniając, że termin „dziennikarz” w tej Konwencji obejmuje wszystkich cywilów, którzy pracują jako reporterzy, korespondenci, fotografowie, kamerzyści, graficy i ich asystenci w dziedzinie mediów drukowanych, radia, filmu, telewizji i mediów elektronicznych (Internet), którzy wykonują swoje zadania na stałej podstawie, w pełnym wymiarze czasu albo częściowym, bez względu na narodowość, płeć i religię, uzgodniły treść Konwencji.

Artykuł 1 stwierdza, że Konwencja będzie obowiązywała w każdym czasie w wojnie i pokoju, podczas międzynarodowych konfliktów zbrojnych (pomiędzy dwoma albo większą ilością Państw), niemiędzynarodowych konfliktów (pomiędzy przeciwnymi grupami wewnątrz obszaru Państwa) i w przypadkach poważnej, wewnętrznej przemocy, co dotyczy także lokalnych konfliktów, zamieszek społecznych, wycelowanych zabójstw, porwań oraz demonstracji bezprawnych i legalnych. Artykuł 2 dotyczy ogólnych warunków i zakłada między innymi, iż jakikolwiek atak albo agresja, pogróżki, porwanie albo zatrzymanie skierowane przeciwko dziennikarzowi podczas wykonywania jego lub jej czynności, jest zabronione, kiedykolwiek i gdziekolwiek ma to miejsce, pod warunkiem oczywiście, że dziennikarz nie podejmuje żadnych działań, które byłyby sprzeczne z jego statusem osoby cywilnej i nie bierze bezpośrednio udziału w operacjach wojskowych. Ponadto zabronione są także jakiekolwiek ataki wymierzone przeciwko medialnym urządzeniom i wyposażeniu, chyba że ich używanie dla celów wojskowych przez zbrojne grupy jest jasno manifestowane. Zakazany jest także jakikolwiek atak przeciwko życiu oraz fizycznej i moralnej integralności, szczególnie zabijanie, okrutne i nieludzkie traktowanie, tortury, branie zakładników, w tym dziennikarzy o każdej porze i we wszystkich miejscach i czyn ten stanowi zbrodnię wojenna, określoną w przepisach międzynarodowego prawa i prowadzi do konsekwencji określonych $\mathrm{w}$ prawie międzynarodowym. W punkcie czwartym, artykuł ten stwierdza, że usługi internetowe muszą być gwarantowane, a kreowane przez media zachęty do przemocy, ludobójstwa, zbrodni przeciwko ludzkości, poważne pogwałcenia prawa humanitarnego są zabronione. Ponadto dziennikarz chcący przyjmować korzyści ochrony przewidziane dla osób cywilnych nie może być nigdy uzbrojony ani przyczyniać się w jakikolwiek sposób działaniom wojennym. Dziennikarze mają możliwość eskorty ze strony wojskowego personelu albo uzbrojonych strażników, dla własnej ochrony oraz ochrony medialnych urządzeń. Artykuł 3 dotyczy wsparcia. Wszystkie Państwa - Strony Konwencji i wszystkie Strony konfliktu zbrojnego, który toczy się na terytorium Państwa - Stro- 
ny Konwencji, muszą zrobić wszystko co możliwe, aby chronić dziennikarzy oraz urządzenia medialne przed atakami, napaścią i zagrożeniami. Przepisy te dotyczą wszystkich dziennikarzy bez wyjątku, czy są oni ,,embedded" (przydzieleni) do wojskowych oddziałów czy towarzyszą konfliktom niezależnie, czy reprezentują organizacje medialne po przeciwnej stronie frontu i wszystkie media towarzyszące konfliktowi bez wyjątku. W związku z tym jakiekolwiek Państwo, strona konfliktu albo państwo trzecie, ma obowiązek wspierania dziennikarzy poprzez dawanie im wolnego dostępu do informacji i wszystkich stosownych dokumentów i ułatwianie im przemieszczania. Artykuł 4 koncentruje się na Media POWS, czyli medialnych jeńcach wojennych, bowiem dziennikarze przetrzymywani podczas konfliktu zbrojnego maja prawo do takiego samego traktowania jak jeńcy wojenni zgodnie z III Konwencją genewską z 12 sierpnia 1949 roku, w szczególności art. 4, paragraf 4, który stanowi, że ,jeńcami wojennymi są osoby towarzyszące siłom zbrojnym, ale nie należące do nich bezpośrednio, jak na przykład [...] korespondenci wojenni”. Artykuł 5 zatytułowany „Dochodzenie i represja” zakłada, że każde Państwo Strona Konwencji powinno natychmiast przedsięwziąć odpowiednie kroki do podjęcia bez zwłoki, szczegółowego i bezstronnego śledztwa w sprawie ataków, zdefiniowanych w art. 2 i postawienia przed sądem przestępców odpowiedzialnych, zgodnie z międzynarodowym i krajowym prawem. Ponadto Strony konfliktu powinny współpracować w ustalaniu faktów i przekazywać swoje ustalenia wyczerpująco i szybko Stronie zainteresowanej. Każde Państwo Strona Konwencji powinno również przedsięwziąć konieczne środki dla zatrzymania zbrodniczo odpowiedzialnej osoby, która angażuje się, nakazuje, nagabuje albo zachęca do ataku, usiłuje popełnić, jest współsprawcą albo uczestniczy w ataku wymierzonym w dziennikarza. Każde Państwo Strona powinno przedsięwziąć wszelkie niezbędne środki do zatrzymania zbrodniczo odpowiedzialnych przestępców. W przypadku, gdy Państwo, nawet jeśli nie jest Stroną Konwencji, nie jest w stanie przeprowadzić śledztwa w sposób bezstronny, w okresie maksymalnie roku i przetrzymać zbrodniczo odpowiedzialnych przestępców, niezależna międzynarodowa komisja dochodzeniowa będzie automatycznie powołana przez Międzynarodowy Komitet Mediów (IMC - International Media Committee). W składzie Komisji dochodzeniowej znajdą się niezależni eksperci i specjalny sprawozdawca Organizacji Narodów Zjednoczonych. Komisja powinna ustalić fakty i zidentyfikować sprawców. Na podstawie działań zostanie sporządzony raport dla IMC i ustanowione zalecenia. Ponadto każde Państwo Strona 
zobowiązuje siebie do ułatwiania pracy międzynarodowej komisji dochodzeniowej. Podejmie także konieczne środki, powstrzymania, zakazania i penalizacji aktów, które przeszkodzą prowadzeniu śledztwa. Artykuł 6 to „Wcześniejsze ostrzeżenie”. I tak w przypadku wojskowego ataku w strefie, gdzie przebywają dziennikarze i znajdują się urządzenia medialne, określone ostrzeżenie powinno być udzielone we właściwym czasie i skutecznymi środkami - reprezentantom medialnym bez wyjątku. Dziennikarze muszą przedsięwziąć wszystkie środki ostrożności, aby uciec ze strefy działań wojennych. Powinni oni zachować poufność, że ostrzeżenie nie wpłynie negatywnie na działania wojenne. Konwencja zakłada także ustanowienie medialnego korytarza, takiego jak te stosowane wobec pracowników humanitarnych, w taki sposób żeby dziennikarze i urządzenia medialne były chronione. Strony w konflikcie powinny również zawiesić działania wojenne podczas uzgodnionego okresu czasu, aby w ten sposób ułatwić dostęp pracownikom mediów. Artykuł 7 dotyczy identyfikacji. W związku z tym, aby wzmocnić ochronę dziennikarzy i ułatwić ich identyfikację w strefach walk, Państwa Strony decydują się przyjąć wyróżniający, międzynarodowy emblemat i zobowiązują się szanować go i zapewniać, że będzie respektowany we wszystkich okolicznościach. Ten międzynarodowy wyróżniający emblemat dla mediów składa się z pięciu dużych liter, PRESS w czarnym kolorze na okragłym, pomarańczowym tle. Dziennikarz noszący wyróżniający emblemat powinien być w stanie udowodnić swoją tożsamość przez pokazywanie karty prasowej albo równoznacznego dokumentu tożsamości, w przypadku kiedy zażąda tego oficer na służbie. Prawo do noszenia emblematu jest zarezerwowane wyłącznie dla dziennikarzy. Ponadto wyróżniający się emblemat powinien być noszony w wyraźnie widocznym miejscu, albo na wierzchu lewego lub prawego ramienia, lub na materiale znajdującym się na klatce piersiowej albo plecach. Pojazdy, profesjonalne wyposażenie i urządzenia medialne mogą być również oznaczone wyróżniającym się emblematem. Ten wyróżniający emblemat powinien być dostarczany przez ten sam związek albo federację dziennikarzy, które wydają kartę prasowąi/albo dokument tożsamości, na prośbę dziennikarza i/albo jego pracodawcy. W przypadku braku związku prasowego w państwie albo tam gdzie owa karta tożsamości nie jest wydawana, karta prasowa dostarczana przez Międzynarodową Federacją Dziennikarzy (International Federation of Journalists - IFJ) albo regionalne stowarzyszenia prasy będzie wystarczająca. Noszenie wyróżniającego emblematu jest opcjonalne we wszystkich okolicznościach. Jego użycie jest wolnym wyborem dziennikarza i/albo jego pracodawcy. Żadna władza nie może 
narzucać noszenia wyróżniającego emblematu. Kiedy dziennikarz decyduje się na nie noszenie emblematu, czerpie korzyści z innych postanowień tej Konwencji. Artykuł 8 zakłada, że każde Państwo Strona zobowiązuje się zapewnić poszanowanie tej Konwencji poprzez szkolenia swojego wojskowego i cywilnego personelu i wszystkich osób, których może dotyczyć, w szczególności przez uszanowanie wyróżniającego emblematu, bezpiecznych stref, humanitarnych medialnych korytarzy, ostrzeżeń, niezależnych dochodzeń, postępowań sądowych. Również stowarzyszenia dziennikarzy i pracodawców zobowiązują się do szkoleń dziennikarzy z przepisów bezpieczeństwa, aby zminimalizować ryzyko. Takie szkolące programy są wolnym wyborem dziennikarzy, ich pracodawców i ich stowarzyszeń. Bezpieczeństwo i solidne wyposażenie musi być jednak dostępne. Dziennikarze muszą być wolni, aby zadecydować, czy chcą podejmować się niebezpiecznych misji w strefach konfliktów albo społecznych rozruchów. Artykuł 9 mówi o zadośćuczynieniu i zobowiązuje każde Państwo Stronę do zapewnienia, żeby ofiara albo w przypadku jej śmierci, rodzina albo ustawowy przedstawiciel, mieli prawo uzyskać zadośćuczynienie i bezzwłoczną, odpowiednią i wystarczającą rekompensatę. Państwa Strony ze stowarzyszeniami dziennikarzy i ich pracodawcami powinny założyć odszkodowawczy Fundusz z realnymi finansowymi zasobami. Państwa Strony powinny także ustanowić system ubezpieczeń, który chroniłby wszystkich dziennikarzy i w sposób znaczący zapewniłby finansową ochronę wolnym strzelcom. W artykule 10 stwierdzono, że aby zapewnić implementację i kontynuację tej Konwencji, Państwa Strony decydują się założyć Międzynarodowy Komitet Mediów (International Media Committee - IMC), którego sekretariat znajdowałby się w Genewie, w Szwajcarii. Może on być zbudowany na istniejącej strukturze pozarządowych organizacji ochrony mediów w Genewie. Komitet powinien składać się z dziesięciu niezależnych ekspertów, którzy powinni służyć swoimi osobistymi kompetencjami i być bezstronni. Pięciu członków Komitetu powinno być wybieranych w tajnym głosowaniu przez Państwa Strony, zgodnie ze sprawiedliwym, geograficznym podziałem z listy kandydatów nie - dziennikarzy. Pięciu kolejnych członków powinno być czynnymi albo emerytowanymi dziennikarzami z uznanymi kwalifikacjami i wybieranymi w tajnym głosowaniu z listy kandydatów, przez stowarzyszenia mediów. Osobami wybranymi będą te, które uzyskają największą liczbę głosów. Przewodniczący Komitetu powinien być dziennikarzem. W przypadku niezgody pomiędzy członkami Komitetu, głosowanie w Komitecie powinno wymagać zwykłej większości plus jeden głos. Pierwsze 
wybory będą miały miejsce przynajmniej pół roku po wejściu Konwencji w życie. Członkowie Komitetu są wybierani na dwa lata i są uprawnieni do reelekcji raz po dwuletnim okresie służby nowego Komitetu. Komitet ustanowi swoje własne reguły postępowania. Powinien on odbywać przynajmniej cztery tygodniowe sesje każdego roku. Państwa Strony, stowarzyszenia dziennikarzy i pracodawców medialnych zapewnią jedną trzecią środków finansowych i zasoby ludzkie niezbędne dla działalności Komitetu. Każde Państwo Strona zobowiązuje się także do współpracy z Komitetem i wsparcia jego członków w wykonywaniu mandatu, szczególnie przekazując im niezbędne informacje. W strukturze poruszanych kwestii, założonych przez tą Konwencję, Komitet powinien współpracować ze wszystkimi odpowiednimi organami, ciałami zajmującymi się prawami człowieka Organizacji Narodów Zjednoczonych, wyspecjalizowanymi agencjami, specjalnymi procedurami Organizacji Narodów Zjednoczonych, międzynarodowymi, regionalnymi i krajowymi organizacjami, pozarządowymi organizacjami, stowarzyszeniami dziennikarzy, zakładami prasowymi, pracodawcami mediów i komisjami etyki. Komitet będzie współpracować z istniejącymi strukturami stowarzyszeń medialnych, regionalnych stowarzyszeń prasowych, aby zbierać wszystkie istotne informacje, dotyczące ogólnoświatowej ochrony dziennikarzy, na podstawie art. 19 Powszechnej Deklaracji Praw Człowieka. Wszystkie Państwa muszą uczynić dostępną odpowiednią informację, której wymaga Komitet. Komitet będzie wydawał coroczne publiczne sprawozdanie i przedstawiał je wszystkim Państwom Członkom Organizacji Narodów Zjednoczonych. W tym sprawozdaniu, Komitet może wydawać Państwom, stowarzyszeniom dziennikarzy, reprezentantom pracodawców mediów - zalecenia. Będzie zapraszał reprezentantów stron i/lub Państw do deklarowania i wezwania ich, jeśli jest to konieczne do przedsięwzięcia środków poprawczych. Komitetowi może być przedłożona każda prośba, która stanowi pilną potrzebę. Prośbę składa ofiara, krewni albo prawni przedstawiciele. Komitet przyjmie prośbę jeżeli większość członków rozpatrzy ją i stwierdzi, że nie jest ona wyraźnie bezpodstawna i nie jest sprzeczna z postanowieniami Konwencji. Prośba może zostać zaakceptowana, nawet jeśli ta sama sprawa jest właśnie analizowana $\mathrm{w}$ innym postępowaniu albo jest słusznie przekazana innemu, międzynarodowemu albo krajowemu organowi. Komitet będzie sprawdzał prośbę i jeśli jest to konieczne, pytał Państwo, Stronę tej Konwencji albo nie, o przekazywanie w ustalonym terminie informacji w danej sprawie. Komitet może również wezwać Państwa do podjęcia wszelkich koniecznych środków, aby polepszyć 
ochronę dziennikarzy albo mediów albo/i dać rekompensatę, kiedy zadośćuczynienie jest konieczne. Jeśli zainteresowane państwo nie odpowie na prośbę Komitetu, może on ustanowić komisję dochodzeniową, na podstawie art. 5 tej Konwencji. Komisja dochodzeniowa może zapewnić wizytę, w porozumieniu z zainteresowanym Państwem. Kiedy nie ma zgody i dialog nie jest możliwy z danym Państwem Członkiem ONZ, Komitet może przedłożyć spór jako pilną sprawę do Rady Praw Człowieka. Komitet jest także zaproszony do przemówienia na publicznej sesji. Członkowie Rady Praw Człowieka mogą zadecydować o zorganizowaniu specjalnej sesji w zgodzie z procedurą tego organu. Komitet będzie także regulował wszelkie spory w oparciu o interpretacje postanowień tej Konwencji. Artykuły 11 i 12 dotyczą kwestii organizacyjnych, gdyż Konferencja Państw Stron będzie miała miejsce rok po wejściu tej Konwencji w życie, a później co dwa lata. Ponadto jakakolwiek Strona Konwencji może proponować zmiany, a zmiana może być przyjęta przez większość dwóch trzecich Państw Stron. Założono również, że Konwencja jest otwarta do podpisu przez wszystkie Państwa Strony ONZ, a dokumenty ratyfikacyjne powinny zostać przekazane Sekretarzowi Generalnemu ONZ. Konwencja wejdzie w życie trzydzieści dni po dacie zdeponowania jej u Sekretarza Generalnego ONZ.

\section{Bibliografia}

Charter for the Safety of Journalists Working in War Jones or Dangerous Areas; http://www.rsf.org/IMG/doc-1353.pdf.

Covering war and disaster, Report on special meeting on media safety and IHL in war reporting, Geneva 26.11.2007; http://www.icrc.org/web/eng/siteeng0.nsf/html/media-ihl-report-261107.

Draft proposal for an International Convention to strengthen the protection of journalists in armed conflicts and other situations, dostępna na stronie http://www.mediacovenant.org/32301.html z 5.05.20068 oraz na http://www.pressemblem.ch/4983.html.

Grochmalski P., Praca dziennikarza w warunkach wojny, „Problemy Humanistyki”. Zeszyty Naukowe WSNHiD, Poznań 1999.

IPI Resolution on the Kidnapping of Journalists. 12.05.2007, http://www.freemedia.at/cms/ipi/statements_detail.html?ctxid=CH0055\&docid=CMS1178978570567.

Konwencja o polepszeniu losu rannych i chorych w armiach czynnych (I konwencja genewska) z 12 sierpnia 1949 r. (Dz. U. 1956, Nr 38, poz. 171, załącznik). 
Konwencja o polepszeniu losu rannych, chorych i rozbitków sił zbrojnych na morzu (II konwencja genewska) z 12 sierpnia 1949 r. (Dz. U. 1956, Nr 56, poz. 175, załącznik).

Konwencja o traktowaniu jeńców wojennych (III konwencja genewska) z 12 sierpnia 1949 r. (Dz. U. 1956, Nr 38, poz. 175, załącznik).

Konwencja genewska o ochronie osób cywilnych podczas wojny (IV konwencja genewska) z 12 sierpnia 1949 r. (Dz. U. 1956, Nr 38, poz. 171, załącznik).

Mallette M. F. red. nauk., Zalety i tajniki dziennikarstwa. Podręcznik dla dziennikarzy Europy Środkowej i Wschodniej.

Oficjalna strona reporterzy.info, www.reporterzy.info.

Oficjalna strona International Press Institute, http://www.freemedia.at/.

Oficjalna strona Committee to Protect Journalists, http://www.cpj.org/.

Oficjalna strona The Reporters Committee for Freedom of the Press, http://rcfp.org/.

Oficjalna strona European Journalism Centre, www.ejc.nl.

Oficjalna strona New Safety Institute, www.newssafety.com.

Oficjalna strona Interntional Federation of Journalists, www.ifj.org.

Oficjalna strona Word Press Freedom Committee, www.wpfc.org.

Oficjalna strona Reporters Without Borders, www.rsf.org.

Oficjalna strona The Press Emblem Campaign http://www.pressemblem.ch.

Oficjalna strona International Covenant for the Protection of Journalists (ICPJ), http://www.mediacovenant.org.

Oficjalna strona „Gazety Wyborczej”, http://wyborcza.pl.

Przybylski J., Żaden reportaż nie jest wart śmierci, Rozmowa z Lucie Morillon, „Rzeczpospolita” z 10.02.2005.

Sobczak J., Korespondent wojenny - ramy prawne i praktyka, w: Wojna. Doświadczenie $i$ zapis. Nowe źródła, problemy, metody badawcze, pod red. S. Buryła, P. Rodak, Kraków 2006.

Święs R., Bezpieczeństwo dziennikarzy w rejonach konfliktów zbrojnych. Sytuacja prawna, problemy, statystyki, w: Wojna. Doświadczenie i zapis. Nowe źródła, problemy, metody badawcze, pod red. S. Buryła, P. Rodak, Kraków 2006.

\section{Summary}

In order to improve the protection of correspondents, the journalists themselves have begun to establish organizations and institutions intended to protect the reporters, or to collect and spread information. The most respectable in this respect is the International Federation of Journalists, seated in Brussels, the largest global organization of journalists. It was established in 1926. Reporters are also aided by the organization Reporters Without Borders (RWB or Reporters sans frontières - RSF) founded in 1985. On November 26, 2007 a conference was held in Geneva where the draft of an international convention on the strengthening of journalists' protection during military conflicts and in other situations was suggested. The draft of this international Convention was subjected to global consultation. 